\title{
Isolation and identification of anticoagulant components from the venom of honey bee (apis mellifera caucasica)
}

\begin{abstract}
The paper presents experimental data on the separation, identification and isolation of anti-coagulant components of the venom of the honey bee Apis mellifera Caucasica, harvested from apiaries from the ecologically clean zone of Azerbaijan. The protein components of zootoxin with molecular masses $41 \mathrm{kD}$ and $20 \mathrm{kD}, 15 \mathrm{kD}$, corresponding to hyaluronidase and phospholipase was isolated from honey bee venom by the method of gel chromatography on a column with Sephadex G-750 eluting with $0.4 \mathrm{M}$ sodium phosphate buffer, followed by spectrophotometric measurement of the unit optical density of the fractions at $\lambda=280 \mathrm{~nm}$ on a Hitachi- 557 spectrophotometer.
\end{abstract}

Volume I Issue 6 - 2017

\author{
Shafiga Topchiyeva, Farida Mammadova \\ Institute of Zoology,Azerbaijan
}

Correspondence: Shafiga Topchiyeva, Institute of Zoology,

Azerbaijan, Email shafiga.topchiyeva@mail.ru

Received: August 09, 2017| Published: September 05, 2017

Keywords: honey bee, apis mellifera caucasica, anticoagulant venom

\section{Introduction}

Despite the presence of a large arsenal of hormonal drugs, antibiotics and other new potent chemotherapeutic drugs, bee venom remains among the most effective medicines, the use of which is expanding. The mechanism of toxic effect of bee venom is very complex and is the result of a complex effect of its components on various organs and systems. Bee venom increases the amount of hemoglobin and blood leukocytes, reduces its viscosity and coagulability and dilates capillaries and small arteries, increasing the flow of blood to the organs. ${ }^{1}$ Separate components of bee venom can be used to achieve certain biological effects. Bee venom also affects the central and peripheral nervous system and can be used to treat patients with heart disease. In the literature, data on the use of bee venom for the treatment of patients with various degenerative diseases of the nervous system, such as multiple sclerosis, Alzheimer's disease and Parkinson's disease and others ${ }^{2-7}$ have been published. $\mathrm{H}$ Zolfagharian, M. Mohajeri, M. Babaie revealed that the bee venom increases the clotting time. By the authors, the honey bee venom were divided into fractions by using gel filtration and chromatography on Sephadex G-50 and their molecular weight was determined by using electrophoresis using sodium dodecyl sulfate in a polyacrylamide gel. Column gel chromatography isolated F1 fraction containing hyaluronidase, F2 and F3 containing phospholipase and F4 containing melittin with molecular masses of 3,15, 20 and $41 \mathrm{kDa}$, respectively. It was noted that fractions F2, F3 and F4 had a greater anticoagulant activity than fraction F1. Thus, the authors consider bee venom as a complex of substances containing an anticoagulant factor consisting of 4 protein fractions with molecular masses of $3,15,20$, and $41 \mathrm{kDa}$. A lethal dose of the whole LD50 venom was determined to be $177.8 \mu \mathrm{g} /$ mouse. ${ }^{8}$ Despite numerous studies on the study of bee venom, the isolation and identification of poison components, a number of questions on the study of their effect on the coagulating blood system of experimental animals are available, the study of which is of great scientific and practical interest. Proceeding from the foregoing, the purpose of these studies was to isolate the anticoagulant fractions from the venom of the honey bee Apis mellifera Caucasica, collected from apiaries from the ecologically clean zone of Azerbaijan.

\section{Material and methods}

The material of the study was the whole venom of the honey bee Apis mellifera Cau-casica, collected from bees from apiaries located in the area of the ecologically clean zone of Azerbaijan, from the territory of the Ismail area. After storage, the venom was stored in a desiccator over a couple of calcium chloride. Venom solutions were prepared immediately before the experiment. Separation of the poison into fractions was carried out by column chromatography on a Sephadex G-75 column measuring $15 \times 150 \mathrm{~mm}$.

To identify the protein components of bee venom, we developed a model technique for the separation of marker proteins. The molecular weights of the marker proteins were determined on a Sephadex G-75 column. For preparation of the column, the matrix G-75 gel was soaked for 48 hours. The prepared gel suspension was carefully filled into a chromatography column. After the height of the layer of the settled gel reached $5 \mathrm{~cm}$, a column crane was opened and a stream of pre-prepared solvent was passed through it, observing the conditions under which the rate of solvent effluent from the column was much less than the flow rate of the solvent during chromatography. After uniform gel settling, the column was washed with a buffer solution and again left for 12 hours at the temperature of chromatography. $0.4 \mathrm{M}$ Na-phosphate buffer solution with a $\mathrm{pH}$ value of 7.0 was selected as the eluent. The volume of the investigated solution of the venom did not exceed $1 \mathrm{ml}$. The elution was carried out with a $0.04 \mathrm{M}$ Na-phosphate buffer solution at $\mathrm{pH} 7.0$ and at a rate of $8 \mathrm{ml} / \mathrm{hr}$.

\section{Research results and discussions}

At construction of the calibration curve, the protein-marcers: Cytochrome $\mathrm{C}$ with $\mathrm{Mm}=12 \mathrm{kD}$, trypsin with $\mathrm{Mm}=20 \mathrm{kD}$, erythrocyte spacecraft with $\mathrm{Mm}=30 \mathrm{kD}$ and albumin lyophilized from human serum with $M m=67 \mathrm{kD}$ were used.. Further, a mixture of marker proteins of $5 \mathrm{mg}$ was passed through a separating chromatographic glass column. The fractions were collected in separate $4.0 \mathrm{ml}$ tubes, followed by measuring the optical density on a spectrophotometer. The quantitative data of spectrophotometric separation of marker proteins are given in (Table 1). Table 1 presents the optical density data 
of the marker-protein fractions separated by gel chromatography on a Sephadex G-75 column. Further, the collected fractions, separated by elution with a $0.4 \mathrm{M}$ solution of Na-phosphate buffer $\mathrm{pH} 7.0$, were combined into separate solutions of marker proteins, followed by measurement of their optical density (Table 2).

Table I Data of spectrophotometric determination of the unit of optical density of protein-marker fractions separated by gel filtration on a column with Sephadex G-75

\begin{tabular}{|c|c|c|c|c|c|c|c|}
\hline $\begin{array}{l}\text { No. of } \\
\text { fractions }\end{array}$ & $\begin{array}{l}\text { The unit of optical } \\
\text { density of fractions }\end{array}$ & $\begin{array}{l}\text { No. of } \\
\text { fractions }\end{array}$ & $\begin{array}{l}\text { The unit of } \\
\text { optical density } \\
\text { of fractions }\end{array}$ & $\begin{array}{l}\text { No. of } \\
\text { fractions }\end{array}$ & $\begin{array}{l}\text { The unit of } \\
\text { optical density } \\
\text { of fractions }\end{array}$ & $\begin{array}{l}\text { No. of } \\
\text { fractions }\end{array}$ & $\begin{array}{l}\text { The unit of optical } \\
\text { density of fractions }\end{array}$ \\
\hline 1 & 2 & 3 & 4 & 5 & 6 & 7 & 8 \\
\hline I & 0.01 & 15 & 0.041 & 29 & 0.026 & 43 & 0.038 \\
\hline 2 & 0.015 & 16 & 0.038 & 30 & 0.022 & 44 & 0.036 \\
\hline 3 & 0.032 & 17 & 0.036 & 31 & 0.020 & 45 & 0.032 \\
\hline 4 & 0.035 & 18 & 0.031 & 32 & 0.018 & 46 & 0.028 \\
\hline 5 & 0.038 & 19 & 0.033 & 33 & 0.032 & 47 & 0.042 \\
\hline 6 & 0.040 & 20 & 0.035 & 34 & 0.034 & 48 & 0.046 \\
\hline 7 & 0.048 & 21 & 0.032 & 35 & 0.036 & 49 & 0.060 \\
\hline 8 & 0.052 & 22 & 0.034 & 36 & 0.040 & 50 & 0.063 \\
\hline 9 & 0.055 & 23 & 0.34 & 37 & 0.050 & 51 & 0.069 \\
\hline 10 & 0.060 & 24 & 0.068 & 38 & 0.085 & 52 & 0.052 \\
\hline 11 & 0.064 & 25 & 0.045 & 39 & 0.060 & 53 & 0.042 \\
\hline 12 & 0.075 & 26 & 0.032 & 40 & 0.048 & 54 & 0.032 \\
\hline 13 & 0.046 & 27 & 0.030 & 41 & 0.035 & 55 & 0.021 \\
\hline 14 & 0.054 & 28 & 0.028 & 42 & 0.033 & 56 & 0.010 \\
\hline
\end{tabular}

Table 2 The separation of marker proteins by gel filtration on a column with Sephadex G-75

\begin{tabular}{llll}
\hline $\begin{array}{l}\text { No. of } \\
\text { fractions }\end{array}$ & Protein markers & VR, ml & $\begin{array}{l}\text { M,thousand } \\
\text { daltons }\end{array}$ \\
\hline I & Albumen & 48 & 67 \\
2 & KA Erythrocyte & 96 & 30 \\
3 & Trypsin & 172 & 20.1 \\
4 & Cytochrome C & 204 & 12 \\
\hline
\end{tabular}

As can be seen from these tables, the marker proteins were arranged in descending order of elution volume - VR, corresponding to an increase in the molecular mass of proteins. Based on the data presented in (Figure 1), it can be seen that the direct proportional dependence of the marker proteins is in the range $12-67 \mathrm{kD}$. Thus, on the basis of experimental data, the separation conditions of the marker proteins were determined by column chromatography using Sephadex G75 followed by spectrophotomet-ric determination of molecular weights, the isolated components in the range of $12-67 \mathrm{kD}$. For the separation and identification the proteins of zootoxin, we sampled $10 \mathrm{mg}$ of bee venom, which were dissolved in $1 \mathrm{ml}$ of bidistilled water and pipetted onto the Sephadex G-75 surface by means of a pipette. Elution of the bee venom proteins was carried out with $0.04 \mathrm{M}$ sodium phosphate buffer. The fractions were collected in a volume of $4 \mathrm{ml}$, followed by a spectrophotometric measure-ment of the unit optical density of the samples at $\lambda=280 \mathrm{~nm}$ on a Hitachi-557 spectrophoto-meter. The data of chromatographic separation of bee venom proteins by the gel filtration method on a column with Sephadex G-75 are presented in (Tables 3) (Table 4) and in Figure 2.

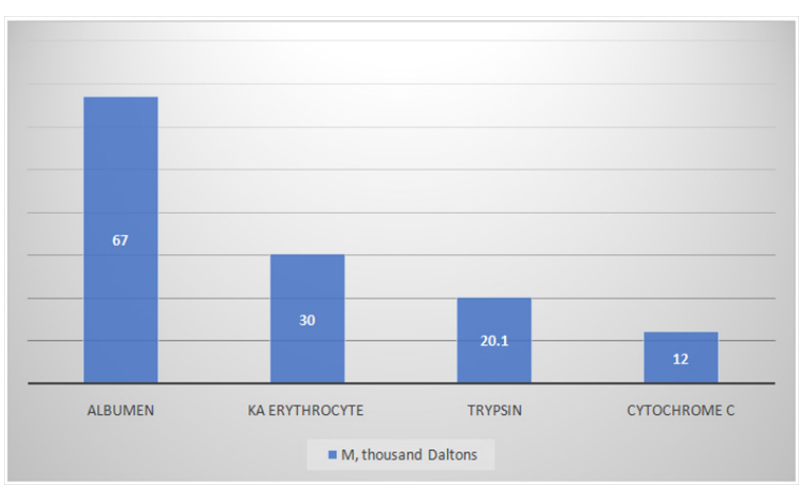

Figure I Direct proportional dependence of the marker proteins is in the range $12-67 \mathrm{kD}$.

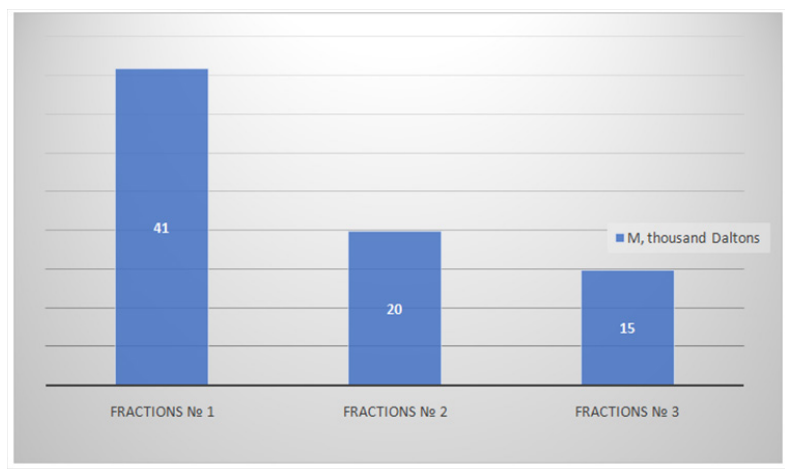

Figure 2 Direct proportional dependence of the bee venom proteins is in the range $|5-4| \mathrm{kD}$. 
Table 3 The optical density data of the honey bee venom fractions separated by gel filtration on a Sephadex G-75 column

\begin{tabular}{|c|c|c|c|c|c|}
\hline $\begin{array}{l}\text { No. of } \\
\text { fractions }\end{array}$ & $\begin{array}{l}\text { The unit of optical } \\
\text { density of fractions }\end{array}$ & $\begin{array}{l}\text { No. of } \\
\text { fractions }\end{array}$ & $\begin{array}{l}\text { The unit of optical } \\
\text { density of fractions }\end{array}$ & $\begin{array}{l}\text { No. of } \\
\text { fractions }\end{array}$ & $\begin{array}{l}\text { The unit of optical } \\
\text { density of fractions }\end{array}$ \\
\hline I & 0.01 & 22 & 0.012 & 43 & 0.050 \\
\hline 2 & 0.018 & 23 & 0.011 & 44 & 0.062 \\
\hline 3 & $0.04 I$ & 24 & 0.012 & 45 & 0.076 \\
\hline 4 & 0.045 & 25 & 0.010 & 46 & 0.040 \\
\hline 5 & 0.052 & 26 & 0.001 & 47 & 0.034 \\
\hline 6 & 0.031 & 27 & 0.010 & 48 & 0.022 \\
\hline 7 & 0.012 & 28 & 0.010 & 49 & 0.015 \\
\hline 8 & 0.011 & 29 & 0.011 & 50 & 0.012 \\
\hline 9 & 0.010 & 30 & 0.012 & 51 & 0.011 \\
\hline 10 & 0.012 & 31 & 0.012 & 52 & 0.010 \\
\hline 11 & 0.001 & 32 & 0.011 & 53 & 0.010 \\
\hline 12 & 0.010 & 33 & 0.010 & 54 & 0.010 \\
\hline 13 & 0.010 & 34 & 0.012 & 55 & 0.010 \\
\hline 14 & 0.011 & 35 & 0.025 & 56 & 0.010 \\
\hline 15 & 0.010 & 36 & 0.036 & & \\
\hline 16 & 0.010 & 37 & 0.048 & & \\
\hline 17 & 0.010 & 38 & 0.056 & & \\
\hline 18 & 0.010 & 39 & 0.078 & & \\
\hline 19 & 0.011 & 40 & 0.062 & & \\
\hline 20 & 0.010 & 41 & 0.036 & & \\
\hline 21 & 0.010 & 42 & 0.022 & & \\
\hline
\end{tabular}

Table 4 Data on the separation of honey bee venom by gel filtration on a fractionation of the venom of the honey bee were determined by gel Sephadex G-75 column

\begin{tabular}{lll}
\hline No. of fractions & VR, $\mathbf{m l}$ & $\mathbf{M m}, \mathbf{k D}$ \\
\hline $\mathrm{I}$ & 20.0 & 41.0 \\
2 & 156.0 & 20.0 \\
3 & 180.0 & 15.0
\end{tabular}
chromatography on a column with Sephadex G-75.

\section{Acknowledgements}

i. Optimal conditions for the separation and identification of proteins of honey bee venom were developed by gel chromatography on a column with Sephadex G-75 eluting with $0.04 \mathrm{M} \mathrm{Na}$-phosphate buffer.

Table 3 shows optical density data of the honey bee venom fractions separated by gel filtration on a Sephadex G-75 columnAs can be seen from (Table 4), as a result of bee venom fractionation by gel chromatography on a column with Sephadex G-75, the investigated venom samples were separated into fragments of fractions of 3 proteins with molecular weights from 15 to $41 \mathrm{kD}$. From these tables, it can be seen that the components of the bee venom are arranged in order of increasing elution volumes-VR, which correspond to the decrease in the molecular masses of proteins. Comparing the obtained data with the data of published sources, it can be stated that the isolated components of the bee venom with molecular masses of $41 \mathrm{kD}$ correspond to hyaluronidase and $20 \mathrm{kD}, 15 \mathrm{kD}$ to phospholipase. The data of chromatographic separation of by the gel filtration method on a column with Sephadex G-75 are presented in (Tables 3) (Table 4) and in. Thus, by the method of column chromatography elution with $0.04 \mathrm{M} \mathrm{Na}$-phosphate buffer, optimal conditions for the

ii. Hemocoagulating proteins of hyaluronidase and phospholipase with molecular masses of $41 \mathrm{kD}$ and $20 \mathrm{kD}, 15 \mathrm{kD}$, respectively, were isolated from the honey bee venom.

\section{Conflict of interest}

The authors declare there is no conflict of interest.

\section{References}

1. https://ftiza.info/deystvie-pchelinogo-yada-na-organizm/

2. Kim JI, Yang EJ, Lee MS, et al. Bee venom reduces neuroinflammation in the MPTP-induced model of Parkinson's disease. Int $J$ Neurosci. 2011;121(4):209-217.

3. Lee SM, Yang EJ, Choi SM, et al. Effects of bee venom on glutamateinduced toxicity in neuronal and glial cells. Evid Based Complement Alternat Med. 2012;368196. 
4. Camila G Dantasa, Tássia LGM Nunesa, Ailma O da Paixãoa, et al. Pharmacological evaluation of bee venom and melittin. Rev bras farmacogn. 2014;24(1):67-72.

5. Münstedt K, Bogdanov S. Bee products and their potential use in modern medicine. JAAS. 2009;1(3):57-63.

6. Abdu Al-Samie MA. Studies on bee venom and its medical uses. IJOART. 202;(2):1-15.
7. Rizzo F, Papasouliotis K, Crawford E, et al. Measurement of prothrombin time (PT) and activated partial thromboplastin time (APTT) on canine citrated plasma samples following different storage conditions. Res Vet Sci. 2008;85(1):166-170.

8. Zolfagharian H, Mohajeri M, Babaie M. Honey bee venom (Apis mellifera) contains anticoagulation factors and increases the bloodclotting time. J Pharmacopuncture.2015;18(4):7-11. 